\title{
Characteristics of Citrus Canker Lesions Associated with Premature Drop of Sweet Orange Fruit
}

\author{
Fabrício E. Lanza, Weber Marti, Geraldo J. Silva, Jr., and Franklin Behlau ${ }^{\dagger}$
}

Fundo de Defesa da Citricultura-Fundecitrus, Departamento de Pesquisa e Desenvolvimento, 14.807-040, Araraquara, São Paulo, Brazil. Accepted for publication 25 June 2018.

\begin{abstract}
During the development of a citrus fruit, many cycles of infection by Xanthomonas citri subsp. citri may occur leading to the development of a range of characteristics of citrus canker lesions scattered across the fruit surface. This study aimed to determine whether the size of the lesions, their distance from the peduncle, and the number and time of appearance of the lesions on fruit of sweet orange were associated with premature fruit drop. A multiple linear regression analysis revealed a negative relationship between the fruit detachment force and the lesion diameter, the proximity of the nearest lesion to the peduncle and the number of lesions. A survival analysis demonstrated that these characteristics significantly influenced the probability and the time that a cankered fruit remained attached to the tree. More than $90 \%$ of dropped fruit had large lesions $(>5 \mathrm{~mm})$ but

not all fruit with large lesions dropped before harvest. Approximately 50\% of the harvested fruit had lesions $>5 \mathrm{~mm}$. On the harvested fruit remaining on the tree, although large, the lesions had a smaller diameter, were located farther from the peduncle, and were less numerous than those observed on dropped fruit. Small canker lesions neither reduced the detachment force nor the survival of fruit in the tree. The earlier a fruit expressed canker symptoms, the higher the probability the fruit developed large lesions near the peduncle and/or developed lesions in greater numbers. This study provides a better understanding on the relationship between the time of appearance of lesions of citrus canker on fruit and premature fruit drop. This information defines the critical period for fruit protection and may be used to improve disease management.
\end{abstract}

Citrus canker, caused by Xanthomonas citri subsp. citri is one of the most serious diseases of citrus in tropical and subtropical production regions (Behlau and Belasque 2014; Gottwald et al. 2002, 2001). Conditions conducive for disease outbreaks occur when growth flushes and fruit expansion coincide with periods of warm temperatures and frequent rainfall associated with gusty winds $(\geq 8 \mathrm{~m} / \mathrm{s})$ (Bock et al. 2010; Gottwald and Graham 2000; Gottwald et al. 2002; Serizawa and Inoue 1974).

Citrus canker affects several citrus species, causing symptoms on leaves, twigs and fruit (Gottwald et al. 2009, 2002; Gottwald and Graham 2000). Lesions on fruit are the most economically important, as they may increase premature fruit drop and reduce marketability of fresh fruit. Direct canker-related crop losses, i.e., fruit drop, in unmanaged trees may range from 40 to $60 \%$, and sometimes as much as $80 \%$. Even when control measures are employed, the trees may show substantial yield losses depending on the variety and favorability of the weather (Behlau and Belasque 2014; Behlau et al. 2017, 2010; Graham et al. 2016a). For the fresh market, canker symptoms on fruit may negate sale, or at best reduce the value of the fruit; lesions on fruit may also impact international fruit trade due to phytosanitary regulation in canker-free citrusproducing areas (Gottwald et al. 2009, 2002; Graham et al. 2016b; Shiotani et al. 2009). Lesions on leaves and twigs are also important as a cause of defoliation, dieback, and impair the development of the trees (Behlau and Belasque 2014; Das 2003; Gottwald et al. 2009).

Canker symptoms begin as pinpoint spots which develop to brownish circular erumpent lesions with a necrotic center surrounded by a water-soaked margin and, most often, a chlorotic halo (Bitancourt 1957; Gottwald and Graham 2000; Gottwald et al. 2002). The lesion size is determined mainly by the age of the host tissue at infection, as well as the citrus species or cultivar affected (Gottwald et al. 2002). Due to the long period of susceptibility to

${ }^{\dagger}$ Corresponding author: F. Behlau; E-mail: franklin.behlau@fundecitrus.com.br

(C) 2019 The American Phytopathological Society
$X$. citri subsp. citri and the occurrence of multiple infection events during development, fruit usually develop larger and less uniformlysized lesions in comparison with leaves (Gottwald and Graham 2000). While leaves are most susceptible from 14 to 28 days after a growth flush begins (one-half to full expansion stage), fruit are more prone to infection by $X$. citri subsp. citri during the first 90 days after petal fall (DAPF). Subsequent to these periods, both leaves and fruit become progressively more resistant to the disease (Gottwald and Graham 2000, 1992; Gottwald et al. 2002; Graham et al. 2016b, 1992; Stall et al. 1982; Vernière et al. 2003).

Some characteristics of canker lesions on fruit have been described as associated with crop loss in citrus species; however, the association has been inferred rather than based on empirical evidence (Bock et al. 2011; Graham et al. 2011, 2010). Previous studies that assessed the efficacy of copper sprays for control of citrus canker on sweet orange and grapefruit described a positive relationship between premature drop and the presence of large lesions resulting from infections early in fruit development (Graham et al. 2011, 2010). Additionally, the high density of canker lesions on the upper surface of grapefruit near the point of attachment (Bock et al. 2011) may exacerbate early abscission of the fruit by inducing ethylene production near the peduncle (Goto et al. 1980; Hyodo 1977; Imaseki et al. 1968; Olson et al. 1970; Williamson and Dimock 1953). However, none of these studies identified the characteristics of canker lesions on fruit that can result in premature drop, nor did they describe the fruit stage at which these lesions appear, which could help citrus growers manage the disease and reduce its impact on yield loss.

Successful control of citrus canker is highly dependent on integrated management which includes the use of copper-based bactericides as an important control measure (Gottwald et al. 2002; Leite and Mohan 1990). Copper sprays provide satisfactory reduction of disease intensity. However, the number and interval of applications may vary and is based mainly on the cultivar, environmental conditions, use of other control measures, while taking into account crop destination (fresh fruit or juice) (Behlau et al. 2010, 2008; Gottwald and Graham 2000; Gottwald et al. 2002; Leite and Mohan 1990; Leite 
et al. 1987). In canker-affected orchards, citrus growers commonly follow a calendar-based schedule of sprays without considering the aforementioned factors, which may lead to under- or over-application of bactericide. Protecting the fruit for a period shorter than its susceptibility phase may reduce the effectiveness of canker control and result in greater crop loss. Conversely, too many applications may waste sprays on stages of the fruit that are no longer susceptible (Graham et al. 2016b, 1992). Unnecessary copper sprays increase the production costs without increasing financial return. Moreover, the excessive use of copper may result in environmental pollution (Fan et al. 2011; Flemming and Trevors 1989; Graham et al. 1986), phytotoxicity (Albrigo et al. 1997; Alva et al. 1995; Schutte et al. 1997) and development of copper-resistant strains of $X$. citri subsp. citri (Behlau et al. 2013).

Knowledge of the characteristics of citrus canker lesions related to premature fruit drop and the developmental phase at which the infections occur may contribute to precisely defining the critical period of protection for copper applications, and consequently improve management of the disease by both increasing the efficiency of chemical control, reducing the number of applications, and thus reducing costs. The objective of this study was i) to characterize the size, location, number, and severity of canker lesions on fruit of sweet orange associated with premature drop, and ii) to determine the time and developmental stage of fruit at which these lesions appear.

\section{MATERIALS AND METHODS}

Characteristics of citrus canker lesions and fruit detachment force. The study was performed in 2013/2014 (trial 1) and 2015/2016 (trial 2) in 8- and 6-year-old commercial orchards of sweet orange 'Valencia' (Citrus sinensis) grafted onto Rangpur lime (Citrus limonia), respectively. The orchards were located in the municipality of Paranavaí $\left(22^{\circ} 59^{\prime} 34^{\prime \prime} \mathrm{S}, 52^{\circ} 36^{\prime} 23^{\prime \prime} \mathrm{W}, 426 \mathrm{~m}\right.$ a.s.1.) and Xambrê $\left(23^{\circ} 47^{\prime} 28.44^{\prime \prime} \mathrm{S} 53^{\circ} 36^{\prime} 00.86^{\prime \prime} \mathrm{W}, 366 \mathrm{~m}\right.$ a.s.1.), respectively, both in Paraná state, Brazil. The orchards received regular weed, pest and disease control, except for the full length of five sequential rows $(\sim 80$ trees in each row $)$ in the middle of the block, where the trials were performed, which did not receive copper applications during the season to ensure canker development on fruit.

Based on previous studies which addressed the diameter of lesions of citrus canker as a possible factor affecting premature fruit drop (Graham et al. 2011, 2010), two fruit sets were sampled immediately before harvest from each orchard: (i) fruit with only small lesion(s) (considered as $\leq 5 \mathrm{~mm}$ in diameter), and (ii) fruit with large lesion(s) (considered as $>5 \mathrm{~mm}$ in diameter), irrespective of the presence of small lesions on the fruit. A group of coalescing small lesions that exceeded $5 \mathrm{~mm}$ in diameter was classified as a large lesion. No fruit with only large lesions was assessed as small lesions invariably occurred alongside large lesions on diseased fruit.

In both experiments, each sample set comprised 90 symptomatic fruit collected from $\sim 50$ different trees in the block. The 90 fruit were selected in groups of 30 depending on lesion proximity to the peduncle and dividing the fruit into three transverse sections based on lesion distance from the peduncle. Thus, depending on the group, the lesions closest to the peduncle occurred in either the upper third, mid third or lower third of the fruit. The fruit detachment force (dependent variable) was measured with a digital dynamometer (Lutron, FG-5020 Force Gauge, Taipei, Taiwan) by attaching the device around the peduncle and pulling the fruit downward. The canker lesions present on the corresponding fruit were characterized (independent variables) based on the sample set. On fruit with small lesions, the diameter and distance of the nearest lesion to the peduncle were measured, the number of lesions counted and the severity of symptoms estimated. On fruit with large lesion (which may or may not have small lesions) the diameter and distance of the nearest large lesion to the peduncle was measured, the number of small and large lesions were counted, and the severity of small and large lesions combined was estimated. The distance of the nearest large lesion to the peduncle was standardized as a proportion relative to the length of the respective fruit (linear distance from the apex to the base of the fruit). Size and distance measurements were performed with a caliper (Eccofer, $150 \mathrm{~mm}$, Curitiba, Paraná). The severity of citrus canker lesions on the fruit was estimated based on the percentage area with lesions using a diagrammatic scale as an aid to improve accuracy (Braido et al. 2014b). As a control, fruit detachment force of 30 healthy fruit with no evidence of lesions of citrus canker was also measured for each trial.

The relationship between each independent variable and the detachment force was determined by multiple linear regression. Subsequently, the independent variables with the highest $t$ and lowest $P$ values were used in nonlinear/linear regression analysis. Because the detachment force of fruit with no citrus canker lesions (control) from the two orchards did not differ $(t$ test, $P<$ $0.05)$, the regression parameters were estimated using the combined data from both trials based on lesion size to increase the robustness of the analysis. All analyses were performed using SigmaPlot 13.0 (Systat Software Inc., San Jose, CA) for both the combined and group data from fruit sets with small and large lesions. The bestfit regression solution based on Akaikes's information criterion (nonlinear regression) or the adjusted coefficient of determination (adjusted $R^{2}$ ) and standard error (linear regression) was selected. Data from all fruit sets, with small and large lesions from both locations, were submitted to a surface response analysis using the software Origin 2016 (OriginLab, Northampton, MA) to explore the association between the two characteristics of canker lesions most related to fruit detachment force (those with the highest $t$ values in the multiple regression analysis). The best-fit regression solution was selected using Akaikes's information criterion.

Characteristics and time of appearance of citrus canker lesions affecting premature fruit drop. This study was conducted in the same seasons and orchards as described previously. In both trial 1 and 2, sets of 50 fruit showing one citrus canker lesion at the earliest visible stage $(\leq 2 \mathrm{~mm})$ were marked monthly (from October to December) after petal fall. The marked fruit were individually wrapped with extruded tubular mesh bags in order to monitor drop. No more than a week after drop or at harvest the canker lesions on the marked fruit were characterized for distance from the peduncle and diameter of the nearest large canker lesion $(>5 \mathrm{~mm})$ to the peduncle irrespective of the presence of small lesions ( $\leq 5 \mathrm{~mm}$ ), fruit length, the number of small and large lesions, and the severity of small and large lesions. In addition, the fruit diameter was measured monthly from the first month the citrus canker symptoms presented until drop or harvest. Measurements of lesion distance from the peduncle, lesion size, and canker severity were performed as described earlier.

Survival analysis was used to compare the survival probability (probability to remain attached to the tree until harvest) and time to drop as DAPF of canker-affected fruit based on the presence of large ( $>5 \mathrm{~mm})$ or small $(\leq 5 \mathrm{~mm})$ lesion(s) and time of appearance of the first canker lesion (October, November, or December). Furthermore, the survival of marked fruit with large lesions was analyzed based on the location of the lesion nearest to the peduncle depending on whether the lesion was located on the upper (proximal to the peduncle) or lower (distal to the peduncle) half of the fruit, the diameter of the lesion nearest to the peduncle (5.1 to $10 \mathrm{~mm}$ or $>10 \mathrm{~mm}$ ), and the number of large lesions ( 1 to 2 or $\geq 3$ ). The fruit survival analyses were performed using SigmaPlot 13.0 by building Kaplan-Meyer curves (nonparametric analysis) and estimating the survival probabilities (Scherm and Ojiambo 2004). The Kaplan-Meyer curves were compared using a log-rank test at $P=0.05$ to test whether the time to drop was significantly affected by the various characteristics of the canker lesions that were assessed. If significantly different, the curves and the average time 
to drop were compared pairwise using the Holm-Sidak test at $P=$ 0.05 and by calculating $95 \%$ confidence intervals, respectively.

In addition, the data were subject to a descriptive analysis of the frequency of total marked, dropped and harvested fruit. The analysis was based on the month of appearance of the first canker lesion and the means of the distance and diameter of the nearest large lesion to the peduncle, and the number of large lesions on all marked, dropped, and harvested fruit.

\section{RESULTS}

Characteristics of citrus canker lesions related to the fruit detachment force. Multiple linear regression analysis revealed a significant relationship between the fruit detachment force and characteristics of canker lesions when the data from fruit with small and large lesions were combined $\left(P<0.001 ; R^{2}=0.40\right)$ and when the fruit with large lesions were analyzed separately $(P<$ $\left.0.001 ; R^{2}=0.47\right)$. However, no significant relationships were observed for any variable with the fruit with only small lesions $(P=$ $0.9 ; R^{2}<0.01$ ) (Table 1). Thus, the multiple regression analysis of data from fruit with large lesions had the highest coefficient of determination. The analysis with the combined data (large and small lesions) showed that the fruit detachment force was negatively related $(P<0.001)$ to the diameter of the lesion nearest to the peduncle, and positively $(P<0.001)$ related to the distance of that lesion from the peduncle, respectively. No relationship was observed between the detachment force and total number of lesions $(P=0.08)$. The analysis of the data from the fruit with only large lesions showed the fruit detachment force was negatively related to the diameter of the lesion nearest to the peduncle $(P<0.001)$, positively related to the distance of that lesion from the peduncle $(P<0.002)$ and negatively related to the number of lesions on the fruit, respectively $(P=0.008)$. As noted, no significant relationships were observed for fruit with only small lesions $(P=0.5)$. The variance inflation factor (VIF) of the severity of lesions of citrus canker on fruit was high in the multiple linear regression analysis, so this variable was removed from all analyses to avoid errors associated with multicollinearity (Kutner et al. 2005).

When the data from small and large lesions were combined, a sigmoid regression solution best described a moderately strong relationship between the detachment force and lesion diameter $(P<$ $0.001 ; R^{2}=0.42$; Fig. $\left.1 \mathrm{~A}\right)$. There was no relationship with the distance from the nearest lesion to the peduncle $\left(R^{2}=0.06\right)$, although the sigmoid model was significant $(P<0.001)$ (Fig. 1D). Furthermore, there was no relationship between the detachment force and the total number of lesions $\left(R^{2}=0.08\right)$, despite the linear model being significant $(P<0.001)$, (Fig. 1G). When regressions were performed using data from fruit with large lesions alone, there were weak to moderately strong relationships with all variables which were best explained by linear regression solutions $(P<0.001$; $R^{2}=0.16$ to 0.40 ) (Fig. 1B, E, and $\mathrm{H}$ ). There was no relationships observed between detachment force of fruit and small lesions $(P>$ $0.5 ; R^{2}<0.01$; Fig. $1 \mathrm{C}, \mathrm{F}$, and I).

The surface response analysis showed a significant interaction between the diameter of the lesion and its distance to the peduncle and the fruit detachment force (Fig. 2). This relationship was best explained by an extreme cumulative model $\left(P<0.001 ; R^{2}=0.45\right)$, which showed that the force required to detach a fruit decreased as the diameter of the lesion increased and as the lesion's proximity to the peduncle increased (Fig. 2).

Characteristics and time of appearance of citrus canker lesions affecting premature fruit drop. In both trials, the probability of a fruit with citrus canker to remain attached to the tree until harvest (survival probability) was dependent on the diameter of the nearest lesion to peduncle $(P<0.001)$ (Fig. 3A and D). In trials 1 and 2, respectively, fruit with small lesions showed a 90 and $98 \%$ chance of remaining attached to the tree or not dropping prematurely because of the disease, as opposed to 58 and $35 \%$ for fruit with at least one large lesion. The average time to drop after petal fall for the fruit with large lesions in each trial (357 and 289 DAPF, respectively) was significantly lower compared with fruit with small lesions (399 and 363 DAPF, respectively).

The retention of symptomatic fruit in the tree was dependent $(P<0.001)$ on the time of appearance of the first canker lesion. The earlier after petal fall the first symptoms appeared, the lower the probability of survival of the fruit, and the shorter the time until premature abscission (Fig. 3B and E). In trial 1, the survival probability of the fruit that showed the first canker symptoms in October ( $\sim 60$ DAPF) was $63 \%$, which was less compared with the $83 \%$ and $100 \%$ survival probability for fruit that expressed the earliest symptoms in November ( $\sim 90$ DAPF) or December $(\sim 120$ DAPF), respectively $(P=0.04)$ (Fig. 3B). However, there was no difference in the average time to drop based on the month of appearance of the first lesion. In trial 1, no fruit that showed symptoms in December dropped before harvest. In trial 2, the survival probabilities of fruit that developed the earliest canker

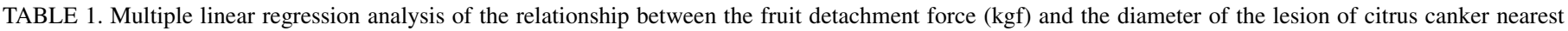

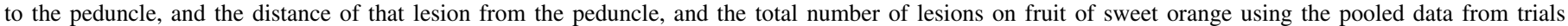
1 and 2 and the fruit sets with large or small lesions and the combination of the two lesion size sets

\begin{tabular}{|c|c|c|c|c|c|c|}
\hline Fruit set ${ }^{\mathrm{a}}$ & Variable & Coefficient of regression $(\beta)^{b}$ & $\mathrm{SE}^{\mathrm{c}}$ & $(F) / t$ & $P$ value & Adjusted $R^{2}$ \\
\hline \multirow[t]{5}{*}{ Large lesion + small lesion } & Regression & & & $(63.393)$ & $<0.001$ & 0.40 \\
\hline & Constant of regression & 9.064 & 0.282 & 32.170 & $<0.001$ & \\
\hline & Lesion diameter $(\mathrm{mm})$ & -0.311 & 0.026 & -11.670 & $<0.001$ & \\
\hline & Distance to peduncle (proportion) ${ }^{\mathrm{d}}$ & 1.302 & 0.341 & 3.818 & $<0.001$ & \\
\hline & Number of lesions & -0.051 & 0.029 & -1.790 & 0.08 & \\
\hline \multirow[t]{5}{*}{ Large lesion } & Regression & & & $(47.966)$ & $<0.001$ & 0.47 \\
\hline & Constant of regression & 10.771 & 0.601 & 17.926 & $<0.001$ & \\
\hline & Lesion diameter $(\mathrm{mm})$ & -0.472 & 0.056 & -8.304 & $<0.001$ & \\
\hline & Distance to peduncle (proportion) & 1.423 & 0.441 & 3.224 & 0.002 & \\
\hline & Number of lesions & -0.267 & 0.098 & -2.704 & 0.008 & \\
\hline \multirow[t]{5}{*}{ Small lesion } & Regression & & & $(0.244)$ & 0.9 & $<0.01$ \\
\hline & Constant of regression & 8.138 & 0.491 & 16.573 & $<0.001$ & \\
\hline & Lesion diameter $(\mathrm{mm})$ & 0.071 & 0.128 & 0.561 & 0.6 & \\
\hline & Distance to peduncle (proportion) & 0.304 & 0.500 & 0.608 & 0.5 & \\
\hline & Number of lesions & 0.003 & 0.046 & 0.070 & 0.9 & \\
\hline
\end{tabular}

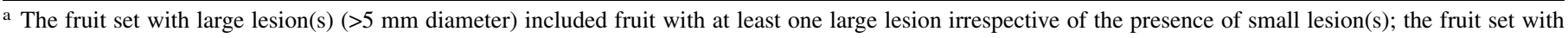
small lesion(s) ( $\leq 5 \mathrm{~mm}$ diameter) included fruit with only small lesion(s).

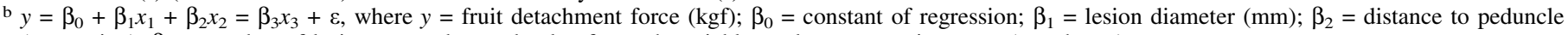
(proportion); $\beta_{3}=$ number of lesions; $x=$ observed value for each variable; and $\varepsilon=$ regression error (not shown).

c Standard error of the regression coefficients.

$\mathrm{d}$ The distance of the nearest small or large lesion to the peduncle was standardized as a proportion relative to the length of the respective fruit. 
lesion were significantly different $(P \leq 0.02)$ in October $(31 \%)$, November $(45 \%)$, and December $(83 \%)$ (Fig. 3E). Likewise, the times for the fruit to drop based on the month the symptom appeared were significantly different $(270,308$, and 353 DAPF in October, November, and December, respectively). In both trials, the appearance of the first canker lesion occurred when the fruit diameter ranged from $\sim 30$ to $45 \mathrm{~mm}$ ( 60 to $120 \mathrm{DAPF}$; October to December) (Fig. 3C and F). No new canker symptoms developed when fruit diameter exceeded $\sim 45 \mathrm{~mm}$ (January to harvest).

The survival probability and time to drop for fruit with large lesions depended on the diameter of the lesion and the distance of the nearest lesion to the peduncle, and the total number of large lesions (Fig. 4). The survival probabilities for fruit with lesion of 5.1 to $10 \mathrm{~mm}$ diameter and fruit with lesions $>10 \mathrm{~mm}$ in diameter were different $(P<0.001)$ in both trials (Fig. 4A and D). However, the time to drop for fruit with more large lesions was significantly shorter only in trial 2 . In trial 1 , when the first large lesion had a diameter of 5.1 to $10 \mathrm{~mm}$ the probability of fruit survival to harvest was $67 \%$ and the time to drop was 364 DAPF, as oppose to $30 \%$ and 337 DAPF, respectively, for fruit with the first large lesion having a diameter $>10 \mathrm{~mm}$ (Fig. 4A). In trial 2, the fruit survival probabilities were 56 and $16 \%$, with times to drop of 325 and 258 DAPF, respectively (Fig. 4D). The position of large lesions influenced the survival probabilities and the time to fruit drop only in the second trial (Fig. 4B and E). In this trial, when the first large lesion was on the lower half of the fruit, the survival probability and time to drop were $55 \%$ and 328 DAPF, respectively, which were significantly greater $(P<0.001)$ when compared with $16 \%$ and 253 DAPF when the first large lesion was on the upper half of the fruit (Fig. 4E). The survival probability and time to drop of fruit that had three large lesions or more were significantly lower compared with fruit with only one or two large lesions in trial 1 $(P=0.04)$ and trial $2(P<0.001)($ Fig. $4 \mathrm{C}$ and F). The incidence of a higher number of large lesions reduced fruit survival probabilities

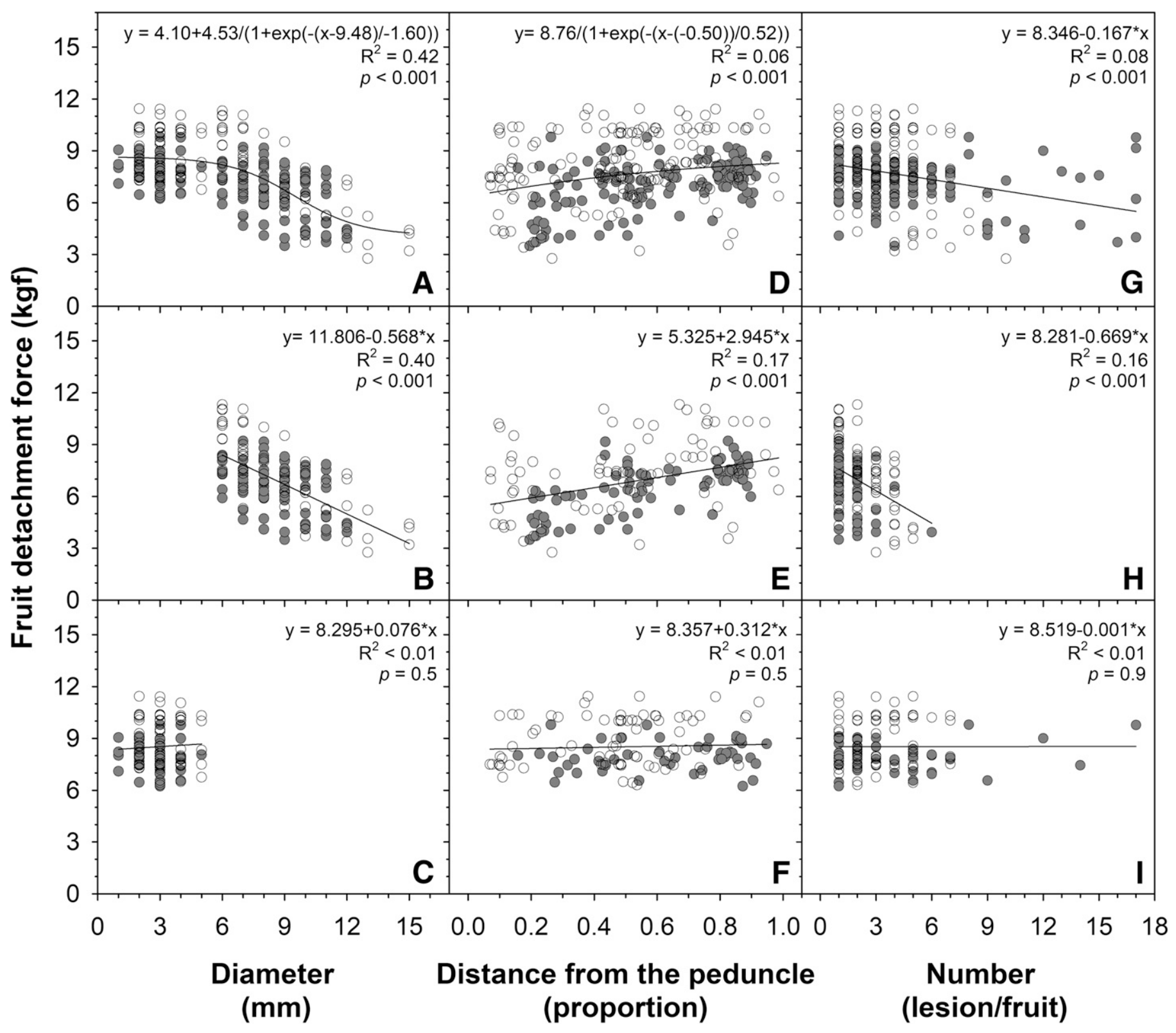

Fig. 1. The detachment force required for fruit from sweet orange trees as a function of $\mathbf{A}, \mathbf{B}$, and $\mathbf{C}$, the diameter of the nearest lesion of citrus canker, $\mathbf{D}, \mathbf{E}$, and $\mathbf{F}$, the distance from the peduncle to the nearest small or large citrus canker lesion, and $\mathbf{G}, \mathbf{H}$, and $\mathbf{I}$, the total number of lesions on the fruit. Sigmoid regression solutions best described the relationships in A and D and linear regression solutions described the remaining relationships in B, C, E, F, and G to I. The distance of the nearest small or large lesion to the peduncle was standardized as a proportion relative to the length of the respective fruit. Gray and white circles represent fruit data from trials 1 and 2 , respectively. 
from 67 to $39 \%$ in trial 1 and from 43.8 to $4.4 \%$ in trial 2 . In comparison with fruit with more than 3 large lesions, the times to drop for fruit with 1 or 2 large lesions decreased significantly from 371 to 327 DAPF and from 303 to 239 DAPF in trials 1 and 2, respectively.

Overall, the earlier the symptoms appeared, the greater the number of fruit with large lesions (Fig. 5A and B). Most dropped fruit had large lesions, but not all fruit with large lesions dropped prematurely. Of the total dropped fruit, 91.3 and $98.5 \%$ had at least one large lesion in trials 1 and 2, respectively (Fig. 5C and D). Conversely, in both trials, the proportion of the total harvested fruit with large or small lesions was approximately 50\% (Fig. 5E and F). Most of harvested fruit with large lesions developed the earliest symptoms in October ( $\sim 60 \mathrm{DAPF})$. Characteristics of large lesions also varied based on fruit age and the time of appearance of the first symptoms (Fig. 5G to L). The final diameter and proximity of the first large lesion to the peduncle and the total number of large lesions on fruit marked in October was higher compared with fruit marked in November or December. The dropped fruit had large canker lesions of greater diameter and proximity to the peduncle, and a greater number of those lesions in comparison with the harvested fruit.

\section{DISCUSSION}

Characteristics of canker lesions including diameter, distance from the peduncle and population size of large lesions, influenced how long fruit remained attached to the tree, which is an important component of crop loss due to the disease. This study demonstrated that the presence of large lesions $(>5 \mathrm{~mm})$ on fruit was the most important characteristic resulting in a reduction of the detachment force. The distance of the nearest lesion from the peduncle and the number of lesions were related to the fruit detachment force only when the lesions were large.

The relationships between the canker variables assessed and the fruit detachment force corroborated the patterns and characteristics

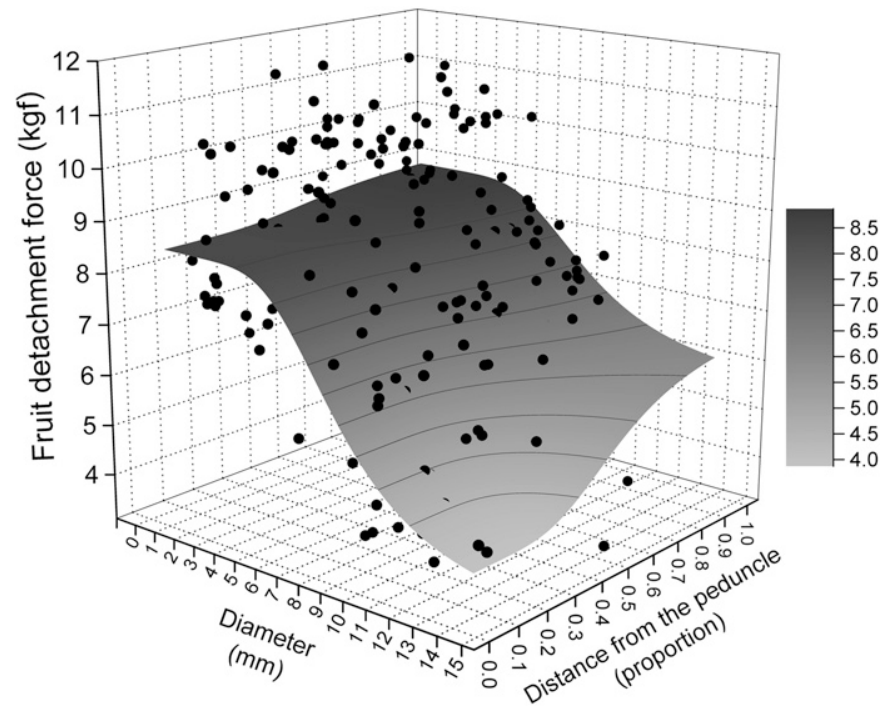

Fig. 2. The detachment force required for fruit from sweet orange trees as predicted by the extreme cumulative model as a function of the diameter and distance of the nearest small or large lesion of citrus canker to the peduncle. The distance of the nearest small or large lesion to the peduncle was standardized as a proportion relative to the length of the respective fruit. The equation for the response surface is $z=8.37-4.69 \times \exp (-\exp (-(x-8.12) /$ $2.35)))+0.46 \times \exp (-\exp (-(y-0.51) / 0.17)))+1.86 \times \exp (-\exp (-(x-8.12) /$ $2.35)))-\exp (-(y-0.51) / 0.17)), R^{2}=0.45, P<0.001$, where $z=$ fruit detachment force, $x=$ diameter of the nearest large or small lesion of citrus canker to the peduncle, and $y=$ distance of the nearest large or small citrus canker lesion to the peduncle. Dots represent the observed data for fruit from trials 1 and 2 . of canker lesions observed on dropped and harvested fruit. Most dropped fruit and only half of the harvested fruit had large lesions $(>5 \mathrm{~mm})$. In general, the harvested fruit had small lesions or large lesions with a smaller average diameter, which were located farther from the peduncle and were less numerous compared with those on the dropped fruit. These observations are in accordance with other studies that reported or discussed an association between early infection and "old" canker lesions developing near the peduncle resulting in premature fruit drop (Bock et al. 2011; Graham et al. 2011, 2010).

Small canker lesions ( $\leq 5 \mathrm{~mm}$ ), irrespective of the distance to peduncle and the number, did not result in a reduction in the detachment force; nor did they affect fruit retention. In both trials, there were trees with fruit that had dozens of small canker lesions that remained attached to the tree until harvest. These trees also had fruit with only one large lesion close to the peduncle that dropped prematurely. This observation emphasized the role of lesion size on fruit drop, and more importantly demonstrated that neither the total number of lesions nor the severity of canker lesions on a fruit are reliable predictors of crop loss due to the disease. Thus, diagrammatic scales for estimating the severity of canker on fruit may not be particularly good indicators of fruit drop (Braido et al. 2014a, b), although they may remain of value for quantifying canker for other purposes.

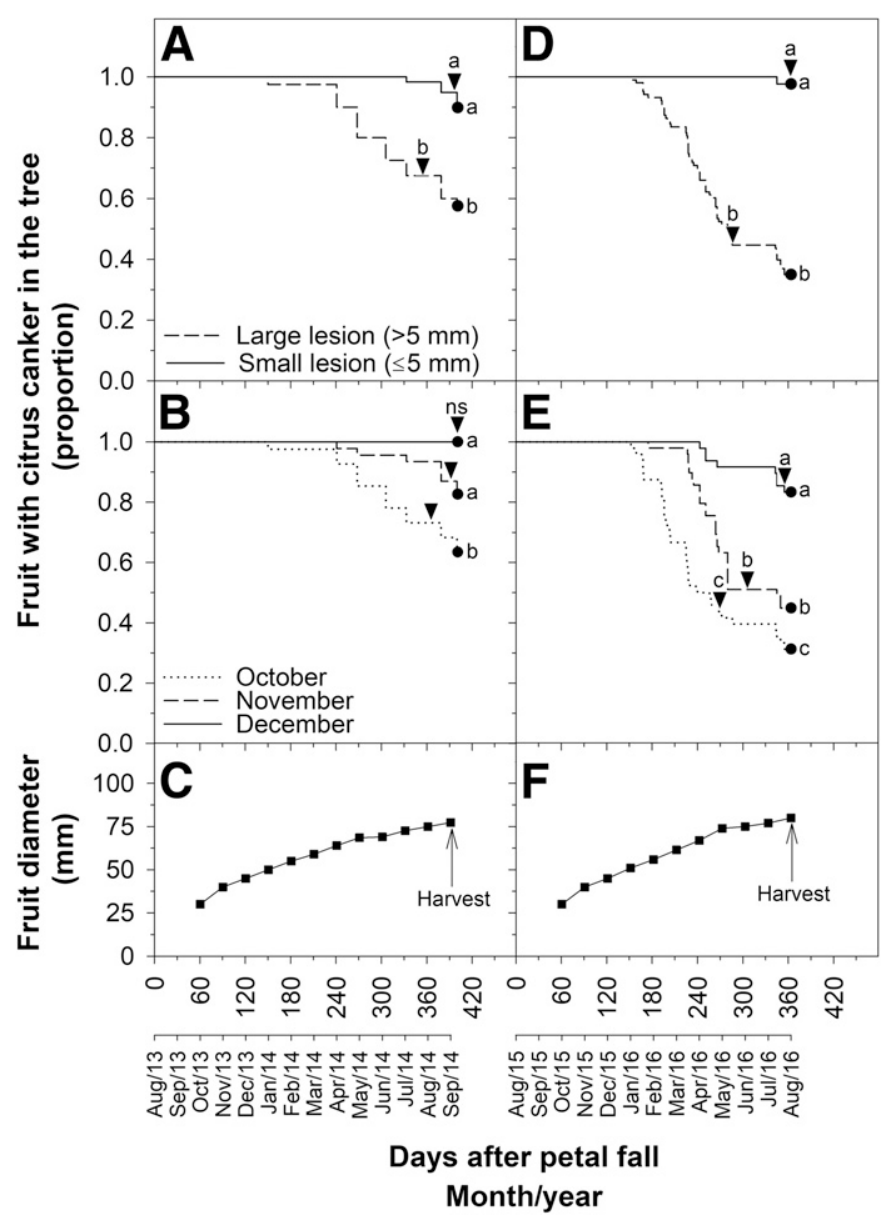

Fig. 3. Kaplan-Meier probability of survival curves for premature detachment of sweet orange fruit based on $\mathbf{A}$ and $\mathbf{D}$, the presence of at least one large lesion or only small lesions and $\mathbf{B}$ and $\mathbf{E}$, the month of appearance of the first lesion on the fruit, and $\mathbf{C}$ and $\mathbf{F}$, fruit diameter from the onset of symptom development until harvest in trails 1 (A, B, and C) and 2 (D, E, and F). Circles and triangles indicate the final fruit survival probabilities and mean time to premature drop, respectively. Circles followed by the same letter do not differ based on the Holm-Sidak test at $P=0.05$. Triangles followed by same letter do not differ based on the $95 \%$ confidence intervals (ns, not significant). 
The association between lesions of citrus canker and premature drop of fruit or leaves may be attributed to ethylene production in the diseased host tissue which culminates with abscission (Goren 1993; Goto et al. 1980; Goto and Yaguchi 1979; Hyodo 1977; Imaseki et al. 1968; Olson et al. 1970; Williamson and Dimock 1953). Ethylene has been demonstrated to be produced following the development of canker lesions on citrus leaves. The abscission of leaves with lesions near the petiole was observed earlier than leaves with lesions located on the distal portion of the leaf blade (Goto et al. 1980). According to Olson et al. (1970) and Williamson and Dimock (1953), a minimum area of injured tissue is necessary to generate the amount of ethylene capable of triggering early abscission of a fruit. The results we obtained corroborated these reports in two aspects: (i) small lesions either did not, or only barely affected the detachment force, and (ii) the fruit detachment force decreased drastically when the diameter of a lesion close to the peduncle was $>5 \mathrm{~mm}$, as demostrated in the regression analysis. Seemingly, only large canker lesions induce the production of sufficient ethylene to reduce the detachment force required for premature fruit drop and that small lesions, irrespective of their number or location, do not promote ethylene production to levels required for fruit abscission. Moreover, as observed for leaves affected with citrus canker (Goto and Yaguchi 1979; Goto et al.

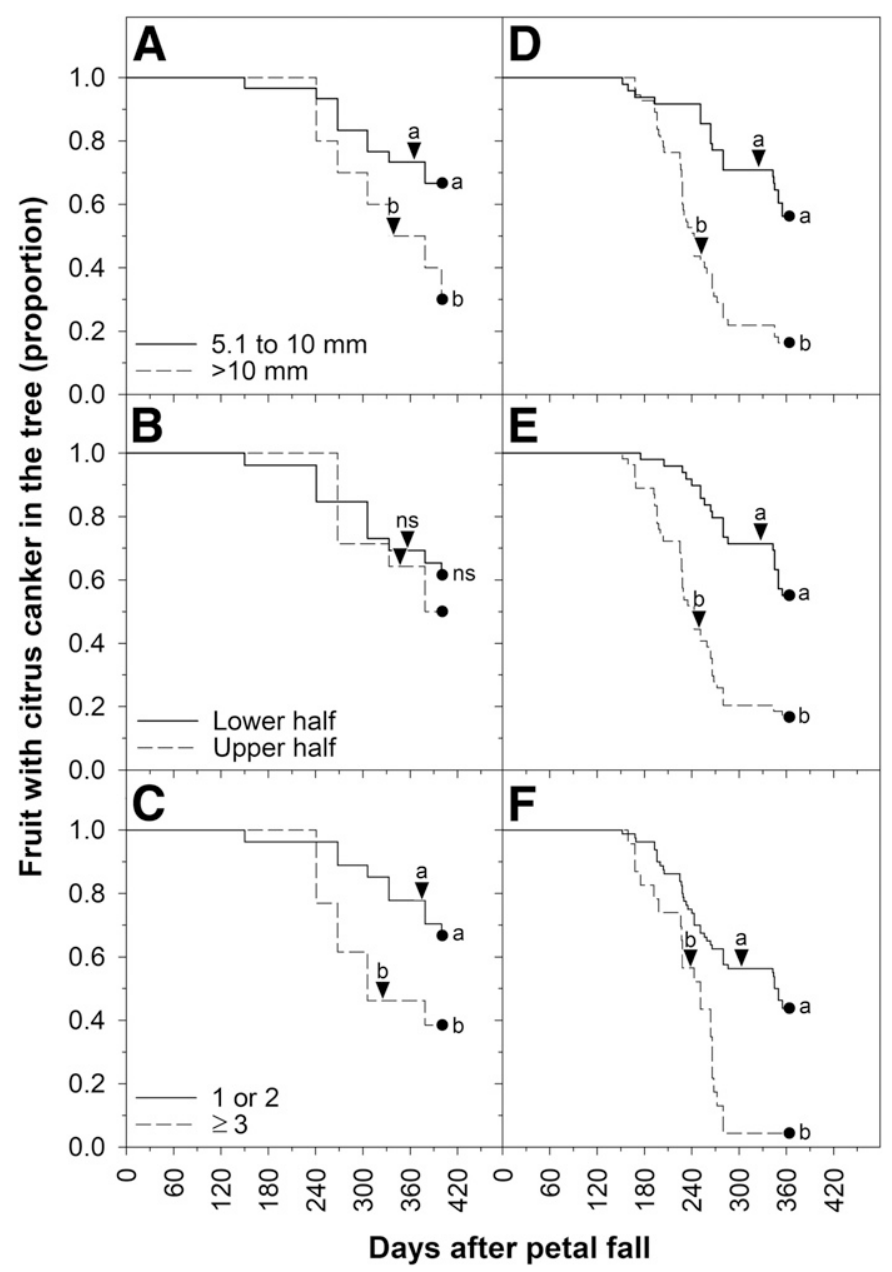

Fig. 4. Kaplan-Meier probability of survival curves for premature detachment of sweet orange fruit based on $\mathbf{A}$ and D, the diameter of the lesion closest to the peduncle, $\mathbf{B}$ and $\mathbf{E}$, the proximity of that lesion to the peduncle, and $\mathbf{C}$ and $\mathbf{F}$, the number of large lesions on the fruit in trials 1 (A, $\mathrm{B}$, and $\mathrm{C}$ ) and 2 (D, E, and F). Circles and triangles indicate the final fruit survival probabilities and mean time to drop, respectively. Circles followed by the same letter do not differ based on the Holm-Sidak test at $P=0.05$. Triangles followed by same letter do not differ based on the $95 \%$ confidence intervals (ns, not significant).
1980), increments in lesion diameter, proximity to the peduncle and the number of large lesions on fruit seem to exacerbate ethylene production and its influence on crop loss through preharvest fruit drop.

The lesion characteristics related to premature fruit drop were also related to the development stage of the fruit when the canker lesion first developed. Fruit were prone to infection and lesion development until they had reached a diameter of $45 \mathrm{~mm}$ or 120 DAPF, which is in agreement with observations by Graham et al. (2016b, 1992). During this period, the young healthy tissue expands continuously and many infection cycles may occur (Dewdney and Graham 2016), resulting in diseased fruit with different numbers
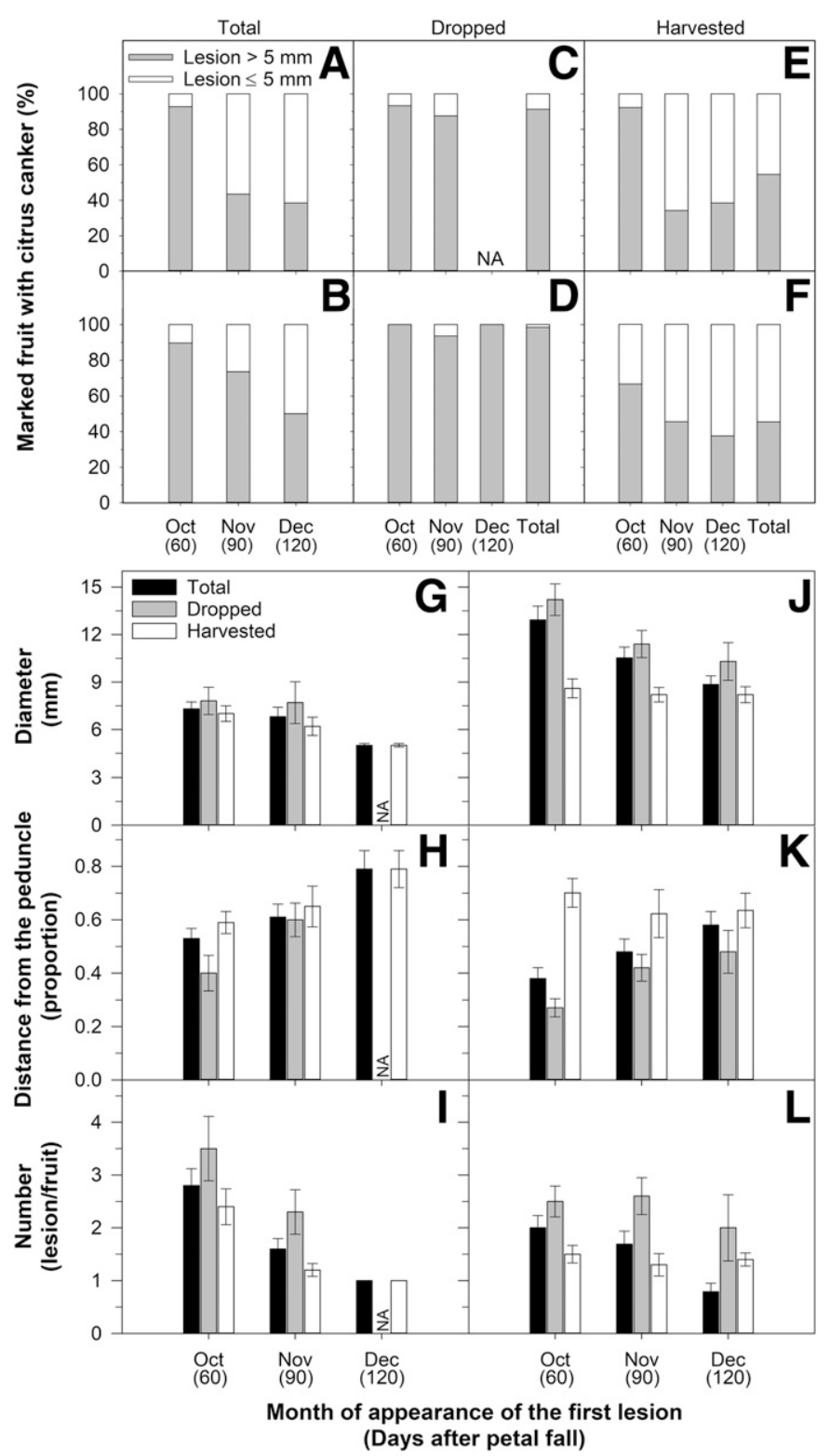

Fig. 5. Percentage of $\mathbf{A}$ and $\mathbf{B}$, total marked, $\mathbf{C}$ and $\mathbf{D}$, dropped, and $\mathbf{E}$ and $\mathbf{F}$, harvested fruit of sweet orange with small $(\leq 5 \mathrm{~mm})$ or large $(>5 \mathrm{~mm})$ lesions of citrus canker (A to F) based on the month after petal fall that the first symptom appeared on the fruit in trials 1 ( $\mathrm{A}, \mathrm{C}$, and $\mathrm{E})$ and $2(\mathrm{~B}, \mathrm{D}$, and $\mathrm{F})$. $\mathbf{G}$ and $\mathbf{J}$, Average diameter of the nearest large lesion of citrus canker to the peduncle, $\mathbf{H}$ and $\mathbf{K}$, the distance from that lesion to the peduncle, and $\mathbf{I}$ and $\mathbf{L}$, the number of large lesions on the total marked, dropped, and harvested fruit of sweet orange based on the month after petal fall that the first symptom appeared on the fruit in trials $1(\mathrm{G}, \mathrm{H}$, and $\mathrm{I})$ and $2(\mathrm{~J}, \mathrm{~K}$, and $\mathrm{L})$. $\mathrm{NA}=$ not applicable, as no fruit drop was observed for fruit that showed the first lesion in December in trial 1. Whiskers indicate the standard error of the mean. 
and sizes of canker lesions scattered across the fruit surface (Bock et al. 2011; Graham et al. 2010, 1992). Our study demonstrates canker lesion characteristics that significantly affect the retention of diseased fruit on the tree: the earlier a fruit develops symptoms of canker, the higher the likelihood the fruit develops large lesions near the peduncle and/or large lesions in a greater number, and consequently, the greater the probability of premature fruit drop.

This information on characteristics of citrus canker lesions that result in fruit drop is of value in defining the critical period of fruit protection against $X$. citri subsp. citri in commercial orchards. The integrated management program for citrus canker adopted in citrus-growing areas where the disease is endemic includes sprays of copper-based bactericides as the primary measure of control (Behlau et al. 2017; Graham et al. 2016a; Leite and Mohan 1990; Leite et al. 1987). The results can help guide citrus growers to schedule copper-based spray programs in accordance with the period of fruit development most at risk and the final use for the crop. For instance, in orange orchards destined for juice production, premature fruit drop caused by large canker lesions is the main cause of crop loss due to the disease, so copper sprays should be targeted toward the early developmental stages of the fruit (up to $\sim 40$ to $45 \mathrm{~mm}$; during $\sim 90$ to $120 \mathrm{DAPF}$ ). Conversely, in orchards destined for the fresh fruit market, where the disease may affect not only the yield but also the quality of the harvested fruit, the calendar of copper sprays should be extended to protect developmental stages of the fruit ( $>45 \mathrm{~mm} ;>120 \mathrm{DAPF}$ ) in order to prevent the appearance of both small and large canker lesions, which may impair fruit marketability. Therefore, this study contributes not only to improve understanding regarding the relationship between characteristics of citrus canker lesions and premature fruit drop, but also provides information that can be used to optimize disease management decisions and minimize production costs while reducing the environmental impact of unnecessary sprays.

\section{ACKNOWLEDGMENTS}

We thank L. H. M. Scandelai and R. Saraiva for technical assistance in the field trials and A. Pratinha (in memorian) for kindly allowing us to collect data in his orchards.

\section{LITERATURE CITED}

Albrigo, L. G., Timmer, L. W., Townsend, K., and Beck, H. W. 1997. Copper fungicide residue for disease control and potential for spray burn. Proc. Fla. State Hortic. Soc. 110:67-70.

Alva, A. K., Graham, J. H., and Anderson, C. A. 1995. Soil pH and copper effects on young "Hamlin" orange trees. Soil Sci. Soc. Am. J. 59: 481-487.

Behlau, F., and Belasque, J., Jr. 2014. Cancro cítrico: A doença e seu controle, 1st ed. Araraquara, São Paulo, Brasil.

Behlau, F., Belasque Junior, J., Bergamin Filho, A., Graham, J. H., Leite Jr, R. P., and Gottwald, T. R. 2008. Copper sprays and windbreaks for control of citrus canker on young orange trees in southern Brazil. Crop Prot. 27: 807-813.

Behlau, F., Belasque Junior, J., Graham, J. H., and Leite Jr, R. P. 2010. Effect of frequency of copper applications on control of citrus canker and the yield of young bearing sweet orange trees. Crop Prot. 29: 300-305.

Behlau, F., Hong, J. C., Jones, J. B., and Graham, J. H. 2013. Evidence for acquisition of copper resistance genes from different sources in citrusassociated xanthomonads. Phytopathology 103:409-418.

Behlau, F., Scandelai, L. H. M., Silva, G. J., Jr., and Lanza, F. E. 2017. Soluble and insoluble copper formulations and metallic copper rate for control of citrus canker on sweet orange trees. Crop Prot. 94:185-191.

Bitancourt, A. A. 1957. O cancro cítrico. Biologico 23:101-111.

Bock, C. H., Gottwald, T. R., and Parker, P. E. 2011. Distribution of canker lesions on the surface of diseased grapefruit. Plant Pathol. 60: 986-991.

Bock, C. H., Graham, J. H., Gottwald, T. R., Cook, A. Z., and Parker, P. E. 2010. Wind speed and wind-associated leaf injury affect severity of citrus canker on Swingle citrumelo. Eur. J. Plant Pathol. 128:21-38.
Braido, R., Gonçalves-Zuliani, A. M. O., Janeiro, V., Carvalho, S. A., Junior, J. B., Bock, C. H., and Nunes, W. M. C. 2014a. Development and validation of standard area diagrams as assessment aids for estimating the severity of citrus canker on unripe oranges. Plant Dis. 98:15431550.

Braido, R., Gonçalves-Zuliani, A. M. O., Nocchi, P. T. R., Junior, J. B., Janeiro, V., Bock, C. H., and Nunes, W. M. C. 2014b. A standard area diagram set to aid estimation of the severity of asiatic citrus canker on ripe sweet orange fruit. Eur. J. Plant Pathol. 141:327-337.

Das, A. K. 2003. Citrus canker-A review. J. Appl. Hortic. 5:52-60.

Dewdney, M. M., and Graham, J. H. 2016. Citrus Canker. Florida Citrus Pest Management Guide. M. E. Rogers, P. A. Stansly, and L. L. Stelinski, eds. University of Florida, Gainesville, FL.

Fan, J., He, Z., Ma, L. Q., and Stoffella, P. J. 2011. Accumulation and availability of copper in citrus grove soils as affected by fungicide application. J. Soils Sediments 11:639-648.

Flemming, C. A., and Trevors, J. T. 1989. Copper toxicity and chemistry in the environment: a review. Water Air Soil Pollut. 44:143-158.

Goren, R. 1993. Anatomical, physiological and hormonal aspects of abscission in Citrus. Hortic. Rev. (Am. Soc. Hortic. Sci.) 15:33-46.

Goto, M., and Yaguchi, Y. 1979. Relationship between defoliation and disease severity in citrus canker. Ann. Phytopathol. Soc. Jpn. 45:689-694.

Goto, M., Yaguchi, Y., and Hyodo, H. 1980. Ethylene production in citrus leaves infected with Xanthomonas citri and its relation to defoliation. Physiol. Plant Pathol. 16:343-350.

Gottwald, T., Graham, J. H., Bock, C., Bonn, G., Civerolo, E., Irey, M., Leite, R. P., Jr., McCollum, G., Parker, P., Ramallo, J., Riley, T., Schubert, T., Stein, B., and Taylor, E. 2009. The epidemiological significance of post-packinghouse survival of Xanthomonas citri subsp. citri for dissemination of asiatic citrus canker via infected fruit. Crop Prot. 28: 508-524.

Gottwald, T. R., and Graham, J. H. 1992. A device for precise and nondisruptive stomatal inoculation of leaf tissue with bacterial pathogens. Phytopathology 82:930-935.

Gottwald, T. R., and Graham, J. H. 2000. Canker. Pages 5-7 in: Compendium of Citrus Diseases. L. W. Timmer, S. M. Garnsey, and J. H. Graham, eds. American Phytopathological Society, St. Paul, MN.

Gottwald, T. R., Graham, J. H., and Schubert, T. S. 2002. Citrus canker: The pathogen and its impact. Plant Health Progress.

Gottwald, T. R., Hughes, G., Graham, J. H., Sun, X., and Riley, T. 2001. The citrus canker epidemic in Florida: The scientific basis of regulatory eradication policy for an invasive species. Phytopathology 91:30-34.

Graham, J. H., Brooks, C., and Yonce, H. D. 2016a. Importance of early season copper sprays for protection of Hamlin orange fruit against citrus canker infection and premature fruit drop. Proc. Fla. State Hortic. Soc. 129: 74-78.

Graham, J. H., Gerberich, K. M., and Davis, C. L. 2016b. Injection-infiltration of attached grapefruit with Xanthomonas citri subsp. citri to evaluate seasonal population dynamics in citrus canker lesions. J. Phytopathol. 164: 528-533.

Graham, J. H., Dewdney, M. M., and Myers, M. E. 2010. Streptomycin and copper formulations for control of citrus canker on grapefruit. Proc. Fla. State Hortic. Soc. 123:92-99.

Graham, J. H., Dewdney, M. M., and Yonce, H. D. 2011. Comparison of copper formulations for control of citrus canker on "Hamlin" orange. Proc. Fla. State Hortic. Soc. 124:79-84.

Graham, J. H., Gottwald, T. R., Riley, T. D., and Bruce, M. A. 1992. Susceptibility of citrus fruit to bacterial spot and citrus canker. Phytopathology $82: 452-457$

Graham, J. H., Timmer, L. W., and Fardelmann, D. 1986. Toxicity of fungicidal copper in soil to citrus seedlings and vesicular-arbuscular mycorrhizal fungi. Phytopathology 76:66-70.

Hyodo, H. 1977. Ethylene production by albedo tissue of satsuma mandarin (Citrus unshiu Marc.) fruit. Plant Physiol. 59:111-113.

Imaseki, H., Uhttani, I., and Stahmann, M. A. 1968. Production of ethylene by injured sweet potato root tissue. Plant Cell Physiol. 9:757-768.

Kutner, M. H., Nachtsheim, C. J., Neter, J., and Li, W. 2005. Applied Linear Statistical Models, 5th ed. McGraw-Hill Irwin, New York.

Leite, R. P., Jr., and Mohan, S. K. 1990. Integrated management of the citrus bacterial canker disease caused by Xanthomonas campestris pv. citri in the state of Paraná, Brazil. Crop Prot. 9:3-7.

Leite, R. P., Jr., Mohan, S. K., Pereira, A. L. G., and Campacci, C. I. 1987. Controle integrado de cancro cítrico-Efeito da resistência genética e da aplicação de bactericidas. Fitopatol. Bras. 12:257-263.

Olson, E. O., Rogers, B., and Rasmussen, G. K. 1970. Abscission of citrus fruit and ethylene production by "Clementine" tangerine fruit grafted onto seedlings infected with stubborn virus. Phytopathology 60:155-157.

Scherm, H., and Ojiambo, P. S. 2004. Applications of survival analysis in botanical epidemiology. Phytopathology 94:1022-1026. 
Schutte, G. C., Beeton, K. V., and Kotzé, J. M. 1997. Rind stippling on Valencia oranges by copper fungicides used for control of citrus black spot in South Africa. Plant Dis. 81:851-854.

Serizawa, S., and Inoue, K. 1974. Studies on citrus canker, Xanthomonas citri. III. The influence of wind on the infection of citrus canker. Bull. Schizuoka Prefect. Citrus Exp. Stn. 11:54-67.

Shiotani, H., Uematsu, H., Tsukamoto, T., Shimizu, Y., Ueda, K., Mizuno, A., and Sato, S. 2009. Survival and dispersal of Xanthomonas citri pv. citri from infected Satsuma mandarin fruit. Crop Prot. 28:19-23.
Stall, R. E., Marcó, G. M., and Canteros, E. B. I. 1982. Importance of mesophyll in mature-leaf resistance to cancrosis of citrus. Phytopathology 72:10971100.

Vernière, C. J., Gottwald, T. R., Pruvost, O., and Réunion, L. 2003. Disease development and symptom expression of Xanthomonas axonopodis pv. citri in various citrus plant tissues. Phytopathology 93:832-843.

Williamson, C. E., and Dimock, A. W. 1953. Ethylene from diseased plants. Pages 881-886 in: Yearbook of Agriculture. A. Stefferud, ed. United States Department of Agriculture, Washington, D.C. 